\title{
Human Rights: Universality and Domination
}

\author{
José Luis Tejeda González ${ }^{1}$ \\ ${ }^{1}$ Research Professor, Universidad Autonoma Metropolitana, CdMX, Mexico \\ Correspondence: José Luis Tejeda González, Universidad Autonoma Metropolitana, CdMX, Mexico.
}

Received: September 30, 2020

Accepted: October 26, $2020 \quad$ Available online: October 28, 2020

doi:10.11114/ijsss.v8i6.5063

URL: https://doi.org/10.11114/ijsss.v8i6.5063

\begin{abstract}
Human rights have been recognized as one of the universal references for excellence. The question of universals has aroused many suspicions and misgivings. They are perceived as theem bodiment of hegemonic and dominant interests. The Universals acquire naturalization because they intend to recover and express the best ideals, values, customs and traditions of the world. It tends to identify them with the levels of civilization and maturation of human communities. They are seen as necessary and unavoidable and raise all kinds of resentments. In the human rights is repited this circumstance where the universal range between consensual and dominant.
\end{abstract}

Keywords: rights, humanity, human rigths, civil liberties, citizenship

\section{Introduction}

In an era characterized by biopolitics, the increasing interference of power and politics over people's lives, human rights remain as the affirmative and defensive referent of citizens. In the face of attempts to accentuate oppressive and inhumane conditions, human rights remain as an inalienable conquest, through which the possibility of giving it a civilized and advanced solution to the destinies of the current world is raised.

In the rights one of the clear points of civilizational convergence is inscribed. And however there is no lack of divergences, controversies and disputes. The universality of human rights is undeniable. The discussion deals about the very meaning of human rights, the form to exercise them and apply them. In the liberal tradition, human rights appear as an extension of the individual, civil, and political rights of Western history. In the despotic tradition, human rights cause discomfort and are applied in collective and social forms, which evade the condition of citizenship and can even get to reject the humanitarian claim.

In human rights, important defining points are reflected on freedom and despotism, universality and particularity. What can be extended to the global and what remains as a particularistic reminiscence. In human rights is one of the lines of defense of a more advanced, inclusive and civilizing project of modernity.

\section{Universals and Domination}

Human rights, as a set of established guarantees, are clearly valid and require constant updating. Linked above all, to the struggle and confrontation with oppressive political systems, authoritarian and totalitarian regimes, dictatorships and tyrannies, they are beyond the political. The policy itself invades spheres of privacy, intimacy, security and existence. The 2020 health crisis, due to the Coronavirus pandemic, only brings up the fragility of human existence, the importance of natural rights, the right to life, and the health associated with it.

The need to guarantee life, to face the pandemic and the disease, to ensure public and private health, leads to the strengthening of relationships of high political and social control, to the restriction and limitation of the freedoms and rights enshrined (Albuquerque, 2020, 8-9). Such a manifest biopolitical circumstance establishes the connection of life and politics, of survival and power. Human rights, once again, must be preserved to avoid situations of involution and political and social regression.

Already globalization, the expansion of capital to planetary levels, indicated us that human rights were in a state of persistent danger and threat. Faced with the permanent challenge to guarantee freedom and democracy, to avoid authoritarian and totalitarian regimes, which tend to crush natural, civil and human rights alike, the proliferation of non-citizenship, dependency and heteronomy is added, of fragility and existential precariousness, of the proliferation of victims. 
The migrant, as one of the clearest phenomena of globalization and contemporary life, puts us suddenly, before the situation of people, deprived of the most basic and elemental rights, thrown into the most precarious and basic condition of human existence, in states of transit and mobility, in the limbo of life, at the intermediate point between "being" and ceasing to "be". There, human rights ensure their absence, as do all minority and oppressed groups that obtain recognition on paper and it is denied in fact. Human rights in their condition of universality, alert us to the common background necessary to build civilized life. The alleged relativization of universal rights, for reasons of belief, religion, culture or civilization, diminishes its international effect (Guerra, 2014, 3-4). Beyond the suspicions about the nature of the universal, it is important to approach the updating and reinforcement of an emancipatory and liberating culture, supported by common values (De Sousa, 2014, 24-25).

In the Middle Ages, there was common the discussion about universals, their existence, and their idealization. Returning to Aristotle, the philosopher Porfirio, he wondered if the genera and species, subsist or only remain in thought $(2010,59)$. The debate went back a long time and extends to the present, but it is worth mentioning the terms in which the matter was dealt with the nominalists. The universal and the general did not exist as such, and only the singular and the particular could claim their real existence (Bertelloni, 2010, 22-23). The generality is reduced to a vagueness, to a lucubration, to what does not land on the real and the true. Contrary to this, it is argued that a consignment and review of the particular is lost in the irrelevant, in the phenomenological, in the pure appearance and in the external of things. To these philosophical discussions is added the relationship of the dominant discourse, of hegemonic languages and of the imposition of general norms from power, with the disguise of universality.

Behind the logos, someone always speaks (Castoriadis, 2007, 13). It is no longer said with the universal. There is an inherent and growing concern that universals are an imposition of one culture and one civilization on the other, a domain of a particular vision that aims to become and do general, expanding its extensions, dominance, jurisdiction and validity. Even in a culture and particular civilization without the pretense of universalization, dominant relationships underlie, which can be oppressive. The imposition is not exclusive of the universality of a theme, a discourse, a resource, a topic, an instrument.

The above is more evident, when a theme broadens its claims of universality, it proclaims itself as civilizing and human and they come into conflict, friction and clash with other cultures and civilizations. That would be happening with the universal treatment of aspects such as freedom, democracy and human rights. All of them, issues related to the western world and the self-proclaimed "free society". In the relationship of the West with the rest of the world there is a persuasive bias, which some insist reflects a desire to impose of a civilization on the rest of the world. In the image that the West has forged on itself, it is insisted that the threats to freedom have come from despotic civilizations, barbarian peoples and enemies that have always haunted the pillars of the free and now modern and industrialized West. The West has engraved an image of otherness, which draws them as the "barbarians", the "savages", the uncivilized, the menacing hordes. The European and Western view of the world takes over the universal, intends to speak from there, to position itself in the strategic place that reflects superiority, preponderance and dominance.

The ethnocentric character of western universalism is asserted through a safe-conduct (Marramao, 1993, 7-8). That would be present in the forging of the predominant universality. In the type of technologies we use and in the dominant mode of speech and language. The processes of destructuring so widespread in the latter part of the last century, helped to rethink the palpable hegemony and predominance in the most presentable universality that attempts to persuade the "others". The cultural relativism so characteristic of anthropology showed that human beings were capable of doing anything, of approaching bestiality quite regularly. Relapse into barbarism is a constant. The West itself is threatened by its own barbarism. The use of the atomic bomb by the United States in the Second World War continues to cause stupefaction, fear and rage, beyond the rationalizations that try to justify and endorse the events of Hiroshima and Nagasaki. Fear of barbarism threatens to turn the West into barbarians (Todorov, 2013, 18). In combating barbarism, the most anachronistic and deplorable methods and practices are used. The road to hell could be full of good intentions.

The universality of the postwar, in values, ideals, references, now so common, it imposed itself to blood and fire and remains the shadow of suspicion and doubt. Some cultures and civilizations tend to prevail over the rest. There is nothing strange in that, the question is whether such predominance is sustained in violence and coercion, or is given with a certain acceptance and natural and spontaneous assimilation. In the points of meeting and common there are areas and territories of socialization, communication and primary universality, which include the use of technological tools and instruments, economic and commercial exchanges, mutual cultural influences, the use of languages and the diffusion of values and customs. It is inconceivable to think about isolation, in hermetic and closed communities, which appeal to fundamental identities. Even in the singularity and national particularity, universal postulates are used, which unite, integrate, communicate and cohere.

Before that so close to the primary, spontaneous and natural universality, born from the recovery and exaltation of what is 
common to human beings, universalism charged with domination and submission is opposed. A universal and predominant criterion and norm is endorsed because it is imposed coercively, because there is no other option and it subjects people to a coercive universality. The laws themselves, supposedly universal, emanating from reason and justice, are accompanied by a coercive, repressive element that makes them prevail and makes them possible. The issue is how much it is imposed the supported universality in the use of crude and relational force and how much it reflects equitable, emancipatory and consensual values. It is difficult and complicated to establish a sharp difference between consensual and coercive universality.

Every system of domination tries not to appear as such, to withdraw into the hidden, to appear as a physical and political violence exercised in the last instance and to give free rein to the economic, religious, ideological, and cultural relations that soften the manifest oppression. In turn, even the most persuasive and consensual has to settle conflict, resistance, insubordination and illegality. Even the best legislation, the fairest legal system, would have to confront real offenders and resort to conviction and criminalization. The most consensual and persuasive universalism acquires a coercive tone when facing its adversaries. If it is a question of defending a justice system, it must even violently confront those who promote injustice. The difference is still substantial, consensual universality seeks understanding, the other is confused with domination and oppression. All this acquires its clearest expression with the debates on freedom, democracy and human rights. In the face of this general debate, how are human rights recorded? What are they, in the light of these references, to the universal and the consensual, to domination and resistance, to justice and oppression?

Human rights become relevant with the maturation of democratic regimes, in the fight and consolidation of civil rights. Human rights are but an extension of the rights enshrined in the modern citizen's constitution. Its antecedents are found in the presumption of innocence of Christianity and in the "ordinary civil process" established in Europe from the 12th century (De Lora, 2006, 7-9). On themes established as universal, such as liberties and democracy, rights in general and human rights in particular, emerged from below and from outside the old European monarchical, aristocratic and feudal regime to consecrate the triumph of the rising bourgeois class. The breakdown of unity and Monolithism of the old regime also affects the system of protection and defense of civil liberties. This is done with the social and popular presence, with the activism of classes and subordinate groups that exceed and surpass the class character of the initial claims.

Although it is true that the system of liberties, democratic demands and civil, political and social rights bring an undeniable bourgeois imprint, they finally escape the logic of the ruling class and are impregnated with other interests, from below and from outside the old and new regimes, for instituting and instituting themselves. They become central and universal referents of the western world, as soon as it is reflected there, a part of the class and social conflict, permeated by multiple interests that blur the character of class and hegemonic exercise. It has been insistently said that such bourgeois order is deceptive and tricky, because it gives a presentable appearance to a social system loaded to the favor of the few and harmful to the majority. That empty shell only covers up and postpones indispensable definitions. The centuries of struggle and confrontation, of dispute and resistance that mark the political and social history of the modern West are denied or underestimated.

It is in issue of liberties, democracy and human rights that the advances made by laborers and workers, women and oppressed sectors, ethnic and racial minorities, discriminated and excluded groups are concreted. It so happens that a system of rights and freedoms, guarantees and entitlements enshrined in Western history serves as a point of reference, for the West itself and the otherness of the world. It is no longer a matter of social class or superior civilization, but a common, universalistic, more representative background brings us closer to the ideals of humanity. The suspicion will continue to prevail that the humanist discourse and language are false and misleading and therefore a reason for caution. We would agree with that, only that the world must seek and find universal references that allow us to develop a project in community, because if not, the particularities are exalted, with their multiple variations to the most brutal and despicable.

There is an instinctive point, of moral philosophy, a "strong valuation" that leads us to discern for what is right (Taylor, 1996, 18-19). It is this predilection for good, which allows us to condemn cannibalism or human sacrifices, human trafficking and slavery, organized crime and institutionalized murder and oppression and lies. Unless it is intended to lead the world to relapse into barbarism and disintegration or social anomie, elements that are integrating, convincing, inclusive and with scope for universality are instituted. Human rights fulfill this task, with all its flaws and drawbacks, assuming an attitude of reserve and caution before the geopolitical and biased use of the issue. It is preferable to build a universal referent of human rights, with the necessary political caution. The latter could allow the proliferation of all kinds of singularities, where the domination and oppression of one or a few is exercised without any limit on the majority of population.

\section{Human Rights: Origins and Development}

The first deviation from centrism and Europeanism is to present the old European continent, its histories and its regional extensions as the only viable and valid referent. The regional and national appropriation of the best in the history of the 
world has its political consequences. If old Europe and the United States appear as the owners of the best stories ever and to be had, it is evident that the universal references and the foundation of domination carry over to that hegemonic story. This has not always been the case, and the exercise of hegemony is filled with deformations of others. Other national, regional and local stories are disdained. They do not give them enough importance and appropriate them. There are elements of tolerance, plurality, and diversity in other ancient stories. Hinduism, for example, has a certain democratic disposition in its ancient culture, due to the existence of ecumenism and polytheism (Norbu, 2001,31-32). Islam exercised tolerance, while the Inquisition prevailed in the Christian West (Kahhat, 2001, 90-91). Equal in the matter of development and economic progress, we will have exemplary stories in other parts of the world.

In human rights we have stayed with the universalist referents in England, France and the United States. The system of gestation and protection of the individual-citizen, the basis of the regime of freedoms and rights in force, is found in these three nations mainly. Specifically in its political and social history of the last 4 centuries. Such construction is complex and contradictory, as is the American constitution, which proclaims the equality of people, on the basis of a slave society (Hunt, 2009, 16-17). This construction has had to be molded, as it happens with other civilizations and cultures. Other stories that appear as non-central should not be disregarded, all the more so since human rights are established as everyone's values.

The resistance of men and people to absolute, tyrannical and despotic power is ancient and has occurred in all areas and on all continents. In European life, it has been named, given a significance and a meaning that the rest of the world appropriates in its own way. If we saw in human rights as an extension of English, French or American domination of the world, we would be condemned not to accept and recognize that a valuable local history can contribute to the universal referents that we are building and erecting. Even more so when it is inclusive and comprehensive.

The challenge is to recover a process and a story with a territorial anchorage, debugging the dominating effect they may have. In fact, such a process and local, regional or national history expresses a relationship of internal forces, it acquires a character of domination and therefore it is worth rescuing the contributions of subaltern, oppressed and marginalized groups. The sense of imperialist domination weakens in the presence of those below and those outside the hegemonic system. Human rights acquire a broader, inclusive and integrating dimension, by connecting with the most invisible and oppressed part.

In other cultures and civilizations there is a similarity, in the maturation of human rights. They are a form of subjective law (De Lora, 2006, 24). Such right aims at the defense of the individual and the person against the interferences, oppressions and dominations of strong and powerful entities. More out of necessity than out of conviction, a legal and juridical system is established that protects the individual and establishes fundamental rights. Later, the importance of giving shape to human rights is endorsed and justified by conviction. From the religious conflicts, the Protestant Reformation and the schism of the Catholic Church, the principle of tolerance is strengthened as something necessary for survival and common coexistence. In the 16th and 17th centuries, tolerance was practiced as a resigned acceptance of difference, to maintain peace (Walzer, 1998, 25-26).

In the learning that establishes the fierce struggle for power and the religious conflict associated with it, a system of protection opens up for people, for minority groups that would be in situation of vulnerability to absolute and unlimited power. With the hand with the English Revolution, the civil wars and the "Glorious Revolution", an institutional framework and a political culture are hatched in England that tries to limit power and guarantee the defense of people's interests. The Tolerance Act of 1689, grants religious freedom and individual political freedom is secured with the abolition of censorship in 1695 (Trevelyan, 1951, 11-12). Liberalism, born and nurtured in this nation, helps to establish human rights.

Rights are appropriate opportunities that can be judicially claimed (Dahrendorf, 1983, 97-98). The history of rights is linked to the evolution of citizenship. Civil rights erupted in the eighteenth century, political rights in the nineteenth and social in the twentieth (Marshall, 1998, 25-26). The first generation of them has to do with individual and civil rights. Later, a differentiated management underlies the theme of human rights. It is alleged that they are linked to liberal social and historical backgrounds of a liberal nature. And for the same reason, they are less applicable and contradict community traditions and collective logics. Human rights, of an economic and social order, are more clearly connected with organization and class resistance, with the structuring of struggles and collective movements. This has given rise to clear tensions in the management of human rights, to the prioritization of some to the detriment of others, to the rejection of some package of human rights, taking refuge the defense of others. A central question is avoided, the human rights would be given by the expansion of a system of guarantees, protection and basic entitlements for the person, individuals and groups of modern society. It begins by protecting people individually, guaranteeing their condition of minimum freedom and not being subject to siege, harassment or persecution by the power in turn.

Individual guarantees and civil rights are at the very origins of human rights. They influence the gestation of a society of 
free individuals, who, however, do not manage to defend themselves, in isolation and in solitude. Hence, the importance of a system of juridical and legal protection. The entitlements granted by habeas corpus and individual rights prevent any power from imposing itself above the citizens, blocking them and inhibiting them in their presence and in their participation. Habeas corpus was embodied in England in a law passed in 1679 (De Lora, 2006, 15). Hence the moral and political condemnation of murder, torture, intimidation of state and government power to free citizens. The exercise of freedom would be impeded if the power in turn got way with hushing, silencing, inhibiting and denying civil liberties.

The right to vote and political participation lead to an extension of the power of citizens. From the condition of subjects and from the predisposition to submission and obedience, one passes on to the open exercise of political rights, to being part of a community, to express an opinion and influence, to demand and question the type of power and politics that the leaders exercise. In the exercise of political rights, the principles of association, demonstration and organization are very clearly found. It is an extension of individual rights, given as a system of minimum guarantees, of security and protection, which now becomes presence and political organization. Individual guarantees and civil rights care and protect to the person against abuse of power. Political rights go further by influencing public life. The defense of the people rises to the group organization for the fight and the distribution of the spaces of power.

Every principle of association and organization carries within itself a concession of personal freedom, for the care of public affairs. It is yielded in individual autonomy, for the sake of superior civil liberty. In Roussonian terms, natural liberty and unlimited law are lost and civil liberty is gained (Rousseau, 1999, 46). The collective and social dimension is in turn sustained in the defense and protection of individual liberties. The liberal tradition guarantees the preservation of personal freedom in collective entities. A collectivist and totalizing treatment could annul individual freedom of the benefit of a group and social sense.

The clash between individual and collective rights is manifested more openly with the irruption of economic, social and cultural rights. Such entitlements move beyond the scope of the individual and therefore lend themselves, for that very reason, to the denial of the most personal and intimate rights. It is argued that individual and civil rights remain in the legal-formal field, and do not attack the social question, which deserves collective responses. The truth is that the proclamation of human rights, by staying in the political legal field, is reduced to the abstract, universal, purely decorative citizen, who does not penetrate deep into the construction of a complete and integral citizenship. Human fullness requires feed, health, education, security, recreation, as well as the civil liberties that made it possible for the claims of subordinate groups to materialize. Care must be taken that such collective rights are not administered by despotic and authoritarian entities, which provide bread and subsistence in exchange for the absence and loss of civil rights. This is a sure route to establishment of the despotism.

Human rights keep us in the line of attention for the progressive humanization of the species. They follow the trend of civil, political and social rights and emphasize the defense of the oppressed and the subjugated. They identify with what distances us from savagery and barbarism, from latent regressions, and seeks to tame the unhealthy of the human condition, reduce it as far as possible and annul it. Instead of using them for abstract and generic evaluations that forget, minimize and suppress the common man, human rights set the basic conditions of ownership to guarantee the existence of individuals and social groups. They are located in defense of minorities and the weak, of victims and vulnerable people, of harassed and persecuted people who speak and adduce from their condition of not power or of the low power that they exercise. It is the situation of oppression by power that makes them particularly sensitive about the human condition. It is not about thinking and looking at the world from the illegitimate privileged place, but from the defense of those who access their humanity, due to their vulnerable state.

We associate the executioner and cruelty with the inhuman, while humanity is with those who have reason and justice, even if they are weak. If an important part of humanity identifies with human rights, with those who defend and promote them, it is because we feel potentially victims and vulnerable. Anyone could suffer the abuses and arbitrariness of despotic, authoritarian and totalitarian powers. Human rights establish a civil, political and social floor, from which humanity is aspired to and attained, it is intended to exercise full citizenship and the abuses of excessive power are limited and obstructed. The complete package of human rights encompasses from individual rights, reaches economic and social entitlements, and leads us to defend vulnerable groups that broaden the collective image of humanity.

The last dimension of human rights, aimed at minority groups, vulnerable and excluded, covers the ethnic, cultural, sexual, reproductive, laggard and pending aspects, trying to overcome all kinds of blockages to the construction of a more humane society. This amalgam, rainbow-type, of the struggle for human rights, in the last phase, is more complex, because it faces when there are still threats and lags in individual, political and social rights. As the expectations of multiculturalism broaden, the reflection of the relationship of the West with the rest of the world, the human rights of other civilizations and cultures and the exercise of collective rights intensifies. Specific protections for vulnerable and minority groups are incorporated, trying not to alter the liberal and equitable sense of social relations (Kymlicka, 1996, 20). There 
is a threat certain, when a theme is so all-encompassing, it is diluted in its contours, it disperses too much. In order to being very inclusive and universalist, multiple specificities and contents are incorporated that alter essential aspects of what human rights mean.

Just as human rights cannot be imposed from the West on the world, much less within its limits, we should have to ask ourselves whether any particular claim, imposed on their communities and civilizations, Does it deserve to be protected and endorsed as a collective right? And from where are we thinking about the universality of human rights? Not only would there be a discussion of what is incorporated into universal human rights, but of what methods, which forms of exercise of power, endorse the existence of cultural singularities. The argument appears that it is the liberal background of open choice, which allows the validation of human rights, forcing to resolve by way of freedom, what would be done with the sediments of tradition, habit and custom, what one does not want to change, and leave without altering the state of things. Even more serious if such a conservative state is supported by despotic forms of power and dehumanized people. Being part of the cupola of a huge power, serving as an executioner or enjoying multiple arbitrary privileges does not generate the slightest humanization, on the contrary. It tends to be insensitive, not to understand the pain of others, to neglect it. It is not about proclaiming the victimization of the world and exalting all kinds of persecuted, humiliated or offended groups. It is the defense of the innocent victims and the unjustly persecuted.

The surviving Nazis after the 2nd World War they are persecuted, harassed, processed and condemned, because of what they did against humanity, they are located in the antipodes of human rights. And the same would apply for other defeated and subdued groups that have caused serious damage to world progress. This is how universal and common criteria are reached with which a particular culture can be weighed, and review its contributions to civilizational progress. It is known that the unitary histories have collapsed and therefore the ultimate referents are blurred, and human rights nonetheless reach a generic condition that indicates us that we are so far away from bestialities and aiming for a better world. The problematic and experimental field of human rights is quite broad and there is no other option but to build provisional universality around its limits and possibilities.

\section{Human Rights: Legality and Factuality}

At this point in world history, it is possible to identify and establish civilizing advances in relation to the full exercise of human rights. Beyond religions, cultures and civilizations, politics and ideology, we would have to evaluate and weigh the civilizational advances by the standard of living and the quality of it for individuals and social groups. It is inadmissible that in order to obtain a high standard of living in the economic, social and material, individual liberties and basic human rights are annihilated, annulled, and relative. It is no less reprehensible that individual rights and entitlements are available while income or basic goods are lacking and limited and scarce. A basic and complete package of individual freedoms and collective rights, allows the right balance to weigh the quality of life of a given citizenry. Human rights acquire an important value to measure the degree of civilization of a society, combining freedoms and basic rights with economic with material progress. Thus, human rights, their presence and incidence, are reflected in people's quality of life.

The possession of titular rights does not like and annoys individuals, groups and institutions that have existed, have been strengthened and become relevant in activities that attempt and harm the rights of people and the universality of those rights. The liberal background of human rights implies that freedom is unlimited and the exercise of power is limited (Merquior, 1993, 16-17). That displeases those who are uncomfortable with the advancement of human rights. What makes them universal referents is the simple fact that any vulnerable person can be reduced to the condition of slave, can be tortured or kidnapped, assassinated or disappear. When a person's human rights are violated, we immediately feel identified because an abuse, a fault, an injustice is committed against the victim and we denounce it and demand reparation for the damage, thus trying to protect ourselves from the same thing happening to us and that those who commit such violations pay for what they do. There is empathy and a sense of group protection. We tend to identify with those who suffer an unjust and reprehensible act, because they touch all of us, potentially and symbolically. The process of involvement with the offended person turns the reprehensible act into something that concerns others, that is, it becomes general and universal. This tortuous, difficult, complicated process includes the condemnation and disqualification of the reprehensible acts, their elevation to legal status and the criminalization of the acts. It is an underground and difficult fight, because for a long time, the most deplorable actions were justified, carried out in the name of God, public order, national security and reason of State.

By establishing the inviolability of the rights of the individual and the citizen, practices and behaviors are condemned, prohibited and penalized, once normal. Arbitrary detentions, "undue process", the use of torture, harassment and threats against individuals and the defendants, homicide from power and forced disappearance, are considered despicable practices that deserve the disapproval and punishment of the society. Limits are placed on power, on judges and executioners, on those who punish and penalize, those who exercised and execute the law. To who exercised excessive power are stripped of authority and strength, and are shown in the mirror of vulnerability, of the possibility of being 
sanctioned by crossing the line in the management and exercise of the power that society has entrusted to them. Before it was not like that, at no time society delegated power to them, since the source of their authority emanated from God and from their own strength.

The background of Christianity derived to a political theology that founds on the one God the transcendence of sovereign power (Agamben, 2008, 13). This makes them feel omnipotent, immune and unpunished, beyond the reach of justice, without being able to be socially sanctioned. Sovereignty is full, as a patent authority and there is no power to bend or subdue them. The limits to the sovereign powers of royalty and aristocracy were beyond the jurisdictional frameworks of the territory they governed. Being an imperishable, eternal, hereditary power, one was born and died with it. There was no greater risk of being punished or prosecuted, because there was no threat "from below" and only in international politics and the war with external adversaries was there any possibility of being defeated and reduced in their sovereign powers. From an unreachable sphere of power, it was difficult to reach humanity to feel vulnerable, fragile and limited. On the contrary, feeling untouchable, allowed the rulers and the ruling classes to approach the most despicable acts, since they would never pay for that. The life of the subjects, of the subordinates, was in the hands of those who governed them and administered their survival and death.

The benevolence and generosity of the ruler were his own qualities that allowed good judgment. They were not a reflection of social or popular pressure or the claim of a particular group. That did not exist or was very weak in the face of the strength of the dominant authority. As kings begin to fall, being beheaded and demolished their empires, they are exposed to the limits of their sovereign power in dealing with their own people, representative groups and factors of power. The revolutionary actions that vex aristocratic and ecclesiastical sectors remain as indelible moments, when the powerful suffer the loss of power, roll through the floor and are exposed to popular derision and social verdicts.

A king, an aristocrat, a tyrant, an executioner, a military man and a policeman did not understand and continue to understand little of human rights. They feel in the fullness of the exercise of unlimited power. In the Nietzschean way, they would suppose that humanization is the absolute exercise of power, the will of power to dry, imposing itself on the soul and body of the victim, the vulnerable, the dispossessed and the fallen into disgrace. According to Nietzsche, where the will to power is lacking, there is decadence $(1997,35)$. Only when they feel and suffer the abuses of power that at some point, they used irresponsibly, harassing others, are they more receptive. In that case, they have already ceased to be in the privileged condition from where they deny the freedoms and rights of others.

It is the condition of not having power or being very weak, which gives another dimension to the pain, the suffering, the damage of the victims. It acquires an ethical and moral tonality, a rational justification and a historical validity that establishes that no matter how much they harm, injure and hurt an innocent victim, reason and justice are not on the side of the aggressor. The sole and absolute exercise of brute force remains without any justification and whoever does not have physical and military power can demonstrate the validity of their cause, since the condition of being victim of a power that is brutally imposed on them, because they cannot do it otherwise way. This explains why certain offices and functions, as well as institutions have an inherent tendency to violate human rights because they only speak with the language of brute force and violent actions. They cannot be imposed in any other way, as is the case with despotic and dictatorial powers. Such social entities and institutions have become accustomed to imposing themselves by force and always getting their way, as happens with businessmen, powerful politicians, the military, the police, the secret services, not to mention what is beyond the law legality, such as organized crime.

The process of constitution of human rights occurs in the ethical, moral and political spheres, but particularly in the juridical-legal sphere. To the extent that legislation with teeth, with legal and criminal implications sanctions practices and behaviors considered normal and habitual in another time, there is a shift in the civilizational rise of human rights. The law fulfills a normative and regulatory function, allied with education and culture. The legal tradition of the law for all, inherited from the Romans, is together with democracy, which lays the foundations of Western civilization (Schianove, 2009, 24-25).

The promotion and encouragement of human rights fall short if they are not supported by legal-political support and the corresponding sanctions. This obliges the variation in the behavior of the authorities themselves and of the previously excessive power, because they must apply the law to their own officials. Sanctions and Criminal punishments are applied to the same power that was previously supposed to be huge and untouched. The resistance to this evolution in the areas of repressive, hidden and uncontrolled power would be capital, since the previously vertical and authoritarian power relations would be reversed and contained by bodies in charge of human rights that sanction the excesses and abuses of arbitrary power. Hence, agents and people, entities and institutions accustomed to the administration and sinister management of power, declare themselves in a state of insubordination in the face of a legality that injures and disables them useless. In the face of who want the world to be sustained itself on violence and insecurity, cruelty and excessive brutality, evil and oppression, human rights put an important dike on them by reversing the perverse game of 
contemporary power.

The vigilant power of the citizenry, of those who do not have power or lack it, they are in a position to defend themselves against absolute, arbitrary and despotic power. Human rights fulfill that civilizing purpose, which sanctions and penalizes, practices and procedures, methods and exercises that tend to dehumanization, to the loss of the human condition, to the bestialization of social relations. In the past decade, the regression in human rights is so great that they have been archived, put aside, minimized and relativized. The attacks of September 11, 2001 and the wars in Afghanistan and Iraq that followed, give rise to all kinds of behaviors that violate and vexat the human rights of Western citizens, let alone those of other cultures and civilizations. If the Western world, if its democratizing component lowers its guard in this regard, the rest of the world does not seem to be very interested in returning to the issue.

By reducing the strategic and civilizing role of human rights, there is a pronounced tendency to despotism and anti-democracy. Disintegration and social decomposition grows and spreads. Obviously, a global dictatorship does not have binding elements and they hardly convince an elite interested in international domination. That if, the relativization and extinction of humanist universalism only leads to the proliferation of the brutality of singularities. The world is being led to an increasingly worse, dehumanized and disintegrated international order.

It has said that the laws only enshrine a state of factual forces, remaining in the legal reproduction of the real state of things and being a legal justification of a dominant and oppressive order. That being true in part, forget one thing. A situation of purely relational power, without the legal referent is even more oppressive, since there are no lines of contention before the strongest, what impose themselves on another and others. The rule of law has been presented as the legal finding of a republican order in which no one is above the law, that it is enfocused to the impartation of justice with impartial criteria and that the written law is the one that marks the limits of what is permitted and what is prohibited, what is socially accepted and what is condemned and penalized. This being the case, the law cannot be reduced to the bare factual. There is an ethical and moral background, a religious, cultural and civilizational reference that establishes the limits of good and evil. In the world of modernity, those limits will be variable, polemical and controversial. Only that the juridical-legal referent is what establishes the possible frameworks of civilized coexistence.

The legal system registers advances in relation to human rights, in relation to the weak and the oppressed, the victims and the subjugated, by providing them help, giving them protection and security, by punishing the abuses and insults of the powerful. It continues to be very limited, because to begin with, the legislation in matter of human rights deals centrally with the acts of the constituted authority, so that the powers that be, individuals, businessmen and others, as well as illegal or illicit factors such as paramilitary groups and organized crime act without any kind of restraint.

The advances in the defense of human rights remain in the legal-public sphere. Despite this, it would be absurd to deny the legal and juridical advances in the matter, because they end up being the universal referent for the treatment of the claims of victimized individuals and collective groups. In some circumstances it is a right without force (Ricoeur, 1985, 11). There remains a wide spectrum in the educational and cultural, which implies persuading, convincing, and inculcating in the population values about human rights.

And the greatest challenge, without a doubt, is in full compliance with the existing normative, in the applying the law to the powerful, institutional or not, who infringe the human rights, violate them and deny them, exceed them and attempt them, and try to turn them into dust and dead letter. This margin so wide that opens between the promulgation of a legal principle and the unrestricted application of the law in favor of the victims, is a propitious field for all kinds of insults, abuses, violations, denials of human rights. If with everything and the existence of a legal framework, human rights are still a civilizing aspiration, we could already suppose what would happen if we stopped taking action on the matter, leaving the issue pending or interrupted, because the powers that are imposed are more stronger than nothing.

\section{Human Rights, International Legislation and Extraterritoriality}

The human rights are linked with universal and civilizing referents, there is no longer any doubt. For that it is why it is necessary to establish a cautious attitude, in the face of the political, ideological and factious use to which the matter would lend itself. Being one of the civilizing elements of the world and remains a central referent for agreements for international coexistence, it must be paid attention and special care. The normative on the matter extends from state and national legislations to international agreements and conventions, which suffer from an initial lack of a physical, political and military force to enforce them. The normative in matter extends from State and national legislation to international agreements and conventions, which suffer from an initial lack of physical, political and military force to enforce them. That is far from being that way.

Just as in International Law, agreements are established on national sovereignty and on the self-determination of nations, it is built a universal legal referent about human rights, which tries to protect and care for the rights of individuals and groups. A very clear paradox opens up, since the international sphere was usually treated as a state of war and conflict, as 
a very clear absence of a world state and an international order. Kant advocated perpetual peace and was suspicious of those pacts that were an armistice, a postponement of war (2012, 43-44). And in international relations predominated the figures of the State and the nation as collective and institutional entities, to the detriment of individuals, citizens and persons.

Human rights first and foremost concern them citizenship. Since Second World War, the European agreement enhances citizenship and allows complaints and demands to be raised before the community level, in order to protect the individual and the person, which introduces an innovative element in International Law and in foreign relations. It is no longer only the treatment between states and nations that matters, but citizenship, with human rights in hand, with guarantees and entitlements takes on importance.

The prevailing norms were limited and restricted to the territorial limits of the national State, as they were before in the royal and imperial sovereignties. A set of provisions international of international order, establish the legal bases for the management of human rights at the planetary level. The most relevant instance of global Criminal Law is the International Criminal Court, which is restricted to crimes committed by a national of a member country or in the territory of a member nation. As it does not have retroactive jurisdiction, it is limited to cases after July 1, 2002 (Swaak, 2004, 61-62). There is no world state, nor a state, physical and military order that enforces them, and however it is a normative element that exerts pressure on nation states, in their excesses, in their overreaches, in their abuses and outrages against individuals and collective groups.

Imbalances, conflicts and contradictions of International Law on the matter are the order of the day. Such right exerts a civilizing and universalistic effect on the atrocities that despotic and arbitrary powers commit against its people. It breaks the notion of inviolability of nations, for the sake of the defense of individuals and citizens, collective groups and repressed and denied minorities. And at some point, unfortunately, both human rights and universal criminal legislation are used for interference and aggression by Western powers against weak nations.

In the 20th century, with the 2 World Wars, the Social Revolutions, the totalitarianisms of the right and the left, the Atomic War and genocides against entire peoples and communities, the universal referent for human rights opens up, the line of civil, peaceful and democratic resistance to stop, brake, contain and disarm the great crimes against humanity. Always controversial and polemical, the notion of humanity expresses an empathetic and supportive interest in others, an attempt to build an international community that makes common cause in the defense of the world's most cherished values. When an outrage, an abuse, a violation, an attack on individual and civil rights is committed, many feel affected and damaged, because potentially they can be in the place of the victim, and much worse, the malevolent entities that they cause so much damage, those monstrosities of the past and now that continue to reproduce, to expand, to feed the most deplorable in human behavior, they continue still there, they persist beyond human rights, which follow the trail.

One of those despicable practices is the expansion and extension of the logic of power to the social and popular sectors, through informants, complicities, submission and servility in the face of oppressive and perverse powers. By giving an endorsement to arbitrary acts of despotic power and mere physical force over others, by being accomplices of the executioners in the mistreatment of the victims, authentic and spontaneous bonds are cracked and broken, empathies and solidarities are destroyed, to be at the mercy of those who oppress and submit. Such is the overwhelming sense of the power of authoritarianism and totalitarianism, beyond ideologies and the colors they wear. Whoever takes the side of the executioners justifies and supports the atrocious power. And there, there is no room for any claim to human rights. They are undermined, they are cornered and annulled, with everything and their legal and juridical validity and with the moral and ethical referent that they transmit.

It is in World War II and its aftermath where an international condemnation of the crimes and atrocities of the Nazis appears. The identification of a common enemy and an absolute evil facilitates the possibilities of international condemnation of fascism and Nazism, of the dictatorships of the extreme right. Naturally, faced with the holocaust, the harassment, the persecution, the extermination and the denial of the Jews, such ethnic-religious group would be the central victim of the 20th century. Such victimization, supported by real and concrete facts, would put them at the center of human rights debates. The impact of the Jewish question on what would be international humanitarian law, emanating from the last part of the last century, was important. Much has been discussed about the role of Jews and the importance they acquire in the contemporary world and in the globalizing process. A people that considers itself elected, in diaspora by the world, without national landing, maltreated in the Second World War, incorporates the notion of humanitarian law at international levels. What is noteworthy is that a victimized group is not exonerated from further criticism, for abuses and crimes committed against another oppressed and subjugated social group. Such would be the case of the State of Israel in relation to Palestine.

Beyond the evolution of the Jewish question, with the Nuremberg trials, the unanimous condemnation of the war crimes of Nazism and the protection of persecuted minorities, the foundations of an international system that defends human 
rights are laid in the post-war period. It is in those years, when it is legalized to international level and a letter of naturalization are acquired the idea that human rights form part of what must be taken care of and protected in the construction of the post-war order. The term crime against lesa humanidad is coined, which seeks to prevent a sovereign State from attempting to annihilate and physically destroy a human social group. The definition of crimes against lesa humanidad appears in the London Statute of 1950, which would serve as the basis for the Nuremberg trials and would have modifications in the legislations elaborated for the cases of former Yugoslavia and Rwanda (Gil, 1985, 139-140). It is intended to inhibit the repetition of the history of the Holocaust, that a tendency such as Nazism access political power and undertake a labor of expansionism, aggression and violence against neighboring and border states and that internal social groups are treated under genocidal parameters and of mass extermination.

The political realism immersed in the elaboration of the universalism of human rights is still controversial. The condemnation of the United States for the bombings of Hiroshima and Nagasaki in 1945 is much less thunderous than the treatment given to the holocaust against the Jews and there is no shortage of justifying them as necessary actions to stop and win the World War. The same is the case with the Soviet Union, whose totalitarianism is excused as a lesser evil to Nazi Germany. In fact, the USSR emerges as the great victorious power of the Nazi threat. The United States and the Soviet Union mount the order of the "Cold War", in which human rights emerge, in a geopolitical environment, which has the Jews as victors and the fascists and Nazis as defeated.

Human rights are associated with geopolitical and strategic management. Almost from the outset, the communist bloc opposes its treatment and is very reluctant to incorporate and accept individual rights, because its repressive nature would be exhibited. The western part of the globe is more clearly dedicated to its promotion. And the complicity of the United States with dictatorships and despotic governments around the world is well known, which cared for and watched over its economic and political interests. It is the rise of global society that puts the issue of human rights on the agenda. Legislation on the matter and the incipient world order in the field of human rights would be used to proclaim the intervention of an international community in the nation States. Interventionism and global interference in the affairs of nations, for humanitarian reasons, are making way. The sovereignty of the States is broken by international law, which is increasingly pressing in the care of victimized individuals and social groups.

In a complex process, the West endorses humanitarian interference, while the United States, the main world power, puts obstacles and dikes to juridical framework and legal universalist. The USA refuses to recognize the International Criminal Court and blocks any possibility of worldwide condemnation of its army and its police and intelligence organs. The United States withdraws from the International Criminal Court as of May 2002 (Garzón, 2004, 34-35). They seek to impose a new world order, with its institutions and its powers acting directly, eluding international organizations, which would be more conducive to neutrality and universality.

Human rights open the world to interference from the global and the international. The difficulty lies in determining which international body is legitimate. The strongest States, the bodies of proto-governmental and even the facto global powers could adjudicate the prerogatives granted by humanitarian intervention. It is a dangerous weapon, which can help civilizational processes and can also injure increasingly weak state sovereignties. In dominant international relations up to the middle of the 20th century, what mattered was the state entity and the nation. From then on, the citizens' rights acquired a naturalization letter, which disrupts the sovereignty of power. A legislation now focused on individuals and citizens makes way for the erosion of state sovereignties, especially in the European case (Held, 1997, 132-133).

The application of International Law to crimes of lesa humanidad had a couple of significant moments, with the Balkan War and the arrest of former Chilean dictator Augusto Pinochet in London. In the first case, the set of NATO countries intervened in the Kosovo crisis in 1998-1999, to stop the conflict between Serbia and the Albanian minority. There was the fear and strategic concern for an ethno-political conflict with dimensions of racial cleansing on the fringes of central Europe. The War of Balkans attracted the interest of the Western powers, leading to the involvement of NATO. Compared to that, in Rwanda, in black and sub-Saharan Africa, there was a complete indifference of the Western world to the atrocious events of the Internal War (Kahhat, 2001, 97-100).

The "humanitarian interference" provokes questions from nationalist and sovereignist groups. The indifference and indolence of the world in the face of the great evils of humanity are no less reprehensible than an interested interference. The establishment of universal referents in the field of human rights weakens the foundations and reason for state and national sovereignties. It is a strategic weapon in civilizing terms and therefore lends itself to a geopolitical and intentional management, allowing the interference of a group of countries against others, while in other circumstances abandonment and disinterest prevail. World organizations such as the UN reflect the balance of international forces and, therefore, are subject to the empire of the strongest and most powerful countries, as well as to an eventual capricious handling of sensitive issues such as human rights.

The other event, no less relevant, is the arrest of Pinochet in 1998-2000, by a court order issued by the European nations. 
It is reflected there both the impossibility of a dictator being judged in the nation where he has immense power, as well as the incidence of international law in the maturation process of a peripheral nation. The positive effect that it acquires for the human rights of the world is undeniable, although it expresses a certain colonial reminiscence, that the "good" comes from the nations of the First World. The dictatorships of the peripheral nations had the endorsement and complicity of the central states of the world, while protecting and serving the interests of global powers. Only when the citizens of the First World are harmed and affected, which are collaterally harmed by dictatorships is that the application of international justice ensue.

We are facing international humanitarian law, with an "opportunist" intervention that exposes and exhibits a dictatorship to the world. Taking advantage of international tools of human rights, a wedge is inserted into dictatorial regimes, accustomed to vexing and subjugating the compatriots. It is International Law, the one from the world community and humanity itself, that takes up the voice of denied and oppressed citizens, to block the exercise of despotic power, which had no one who could oppose it. The great challenge is to generate and practice a humanized international law, less linked to factual and global interests, more distant from neocolonialism, less conditioned by political realism, which would be its negation and its failure. Human rights would be one of the main threads to envision a more civilized and advanced international community.

\section{Conclusions}

It is an extremely serious fault, to suppose that particular and singular realities can achieve validity by themselves. In an increasingly integrated and globalized world, universal and civilizing referents are needed to guide individuals and citizens, social groups, nations and communities on a path that we lead to a better world, more balanced and just human world. Despite how difficult and complicated it is to build the universal in the social and political, it is more harmful to pretend that the atavisms of the local and the regional are imposed and reproduced. As with technology - which is not neutral either - communities, peoples and nations learn from the best and most advanced of the rest of humanity. A particular reality comes to be presented as universal, to the extent that it persuades and convinces, that it demonstrates a validity above other prevailing circumstances. Human rights fall into this orbit, which can be considered to achieve universality.

However, a vigilant and provisional attitude must be maintained in the face of the same human rights problem. They must be prevented from serving as a colonialist weapon, imposing a culture and civilization on the rest of humanity. That which is implanted by force, in itself denies the humanitarian possibility. Human rights protect the rights of individuals and citizens, human groups and communities. In order to reaffirm the universality of which they appear as bearers, as an element that binds the common, human rights have to take care, not to become a powerful instrument at the service of particular, factious and illegitimate interests. The state of constant review of human rights concerns the inherent necessity to maintain a convincing and latent universality. Human rights prove a substantial vehicle for raising civilizing conditions and citizen coexistence in the world. An abusive use of human rights, in the relationship of the universal with the particular, weakens the emancipatory potential that they express and represent. Hence, the necessity for reflection and correction over human rights, their exercise and their application.

\section{References}

Agamben, G. (2008). El Reino y la Gloria. Una genealogía teológica de la economía y del gobierno. Homo sacer, II, 2. Buenos Aires: Adriana Hidalgo.

Albuquerque, A. (2020). La pandemia de COVID-19 desde una perspectiva de derechos humanos. In Albuquerque, Aline \& Kalline Eler (ed.), Derechos humanos de los pacientes y COVID-19 (pp. 6-9). Brasilia: UNESCO/University of Brasilia.

Bertelloni, F. (2010). Estudio preliminar. In Marcheto, María Florencia \& Antonio Tursi (Introduction, translation and notes), La cuestión de los universales en la Edad Media. Selección de textos de Porfirio, Boecio y Pedro Abelardo (pp. 11-51). Buenos Aires: Winograd.

Castoriadis, C. (2007). La Institución imaginaria de la sociedad. Buenos Aires: Tusquets.

Dahrendorf, R. (1983). Oportunidades vitales. Notas para una teoría social y política. Madrid: Espasa-Calpe.

De Lora, P. (2006). Memoria y frontera. El desafío de los derechos humanos. Madrid: Alianza.

De Sousa, S. B. (2014). Derechos humanos, democracia y desarrollo. Bogota: Colección de Justicia.

Garzón, B. (2004). Los fundamentos de la jurisdicción penal universal. In Moreno Hernández, Moisés (ed.) El Estatuto de Roma. El Estatuto de la Corte Penal Internacional y sus implicaciones en el Derecho Nacional de los Países Latinoamericanos (pp. 33-46). México City: Ius Poenale/Centro de Estudios de Política Criminal y Ciencias Penales, A. C. (CEPOLCRIM). 
Gil Gil, A. (2004) Los crímenes contra la humanidad y el genocidio en el Estatuto de la Corte Penal Internacional. In Moreno Hernández, Moisés (ed.) El Estatuto de Roma. El Estatuto de la Corte Penal Internacional y sus implicaciones en el Derecho Nacional de los Países Latinoamericanos (pp. 131-176). México City: Ius Poenale/Centro de Estudios de Política Criminal y Ciencias Penales, A. C. (CEPOLCRIM).

Guerra, S. D. (2014) Los derechos humanos: situación actual y perspectivas. Encuentros multidisciplinares, 46, 1-7. Madrid: Universidad Autónoma de Madrid.

Held, D. (1997). La democracia y el orden global. Del Estado moderno al gobierno cosmopolita. Barcelona: Paidós.

Hunt, L. (2009). La Invención de los derechos humanos, Barcelona: Tusquets.

Kahhat, F. (2001). Derechos humanos, ¿universales u occidentales? Istor. Revista de Historia Internacional, 4, 87-101. México City: Centro de Investigación y Docencia Económica (CIDE)/ División de Historia.

Kant, I. (2012). Sobre la paz perpetua. Madrid: Akal.

Kymlicka, W. (1996). Ciudadanía multicultural. Una teoría liberal de los derechos de las minorías. Barcelona, Paidós.

Marramao, G. (1993). Paradojas del universalismo. Revista Internacional de Filosofía Política, 1, 7-20. Madrid: Universidad Nacional de Educación a Distancia (UNED) / Universidad Autónoma Metropolitana (UAM)Iztapalapa.

Marshall, T. H., \& Tom, B. (1998). Ciudadanía y clase social. Madrid: Alianza. https://doi.org/10.2307/40184017

Merquior, J. G. (1993). Liberalismo viejo y nuevo. México City: Fondo de Cultura Económica.

Nietzsche, F. (1997). El Anticristo, maldición sobre el cristianismo. Madrid: Alianza.

Norbu, D. (2001). El pueblo indio: demócrata por naturaleza. Istor. Revista de Historia Internacional, 4, 29-37. México City: Centro de Investigación y Docencia Económicas (CIDE) / División de Historia.

Porfirio. (2010). La Isagoge de Porfirio. In Marcheto, María Florencia \& Antonio Tursi (Introduction, translate and notes), La cuestión de los universales en la Edad Media. Selección de textos de Porfirio, Boecio y Pedro Abelardo (pp. 53-105). Buenos Aires: Winograd.

Ricoeur, P. (1985). Fundamentos filosóficos de los derechos humanos. In Diemer, A., et. al. Los fundamentos filosóficos de los derechos humanos (pp. 9-32) Barcelona: Serbal/UNESCO.

Rousseau, J. J. (1999). El contrato social o principios de derecho político. México City: Losada/ Océano.

Schiavone, A. (2009) IUS. La invención del derecho en Occidente. Buenos Aires: Adriana Hidalgo.

Swaak, O. (2004). El desarrollo del derecho penal internacional. In Moreno Hernández, Moisés (ed.) El Estatuto de Roma. El Estatuto de la Corte Penal Internacional y sus implicaciones en el Derecho Nacional de los Países Latinoamericanos (61-69). México City: Ius Poenale/Centro de Estudios de Política Criminal y Ciencias Penales, A. C. (CEPOLCRIM).

Taylor, C. (1996). Fuentes del yo. La construcción de la identidad moderna. Barcelona, Paidós.

Todorov, T. (2013). El miedo a los bárbaros. Más allá del choque de civilizaciones. México City: Galaxia Gutenberg/Círculo de Lectores/Colofón.

Trevelyan, G. M. (1951). La revolución inglesa: 1688-1689. México City: Fondo de Cultura Económica.

Walzer, M. (1998). Tratado sobre la tolerancia. Barcelona: Paidós.

\section{Copyrights}

Copyright for this article is retained by the author(s), with first publication rights granted to the journal.

This is an open-access article distributed under the terms and conditions of the Creative Commons Attribution license which permits unrestricted use, distribution, and reproduction in any medium, provided the original work is properly cited. 